\title{
Evaluation of the knowledge of intern doctors on transfusion medicine in Turkey
}

Funda Tayfun Kupesiz ( $\square$ fundatyfn@gmail.com )

Antalya Egitim ve Arastirma Hastanesi https://orcid.org/0000-0003-2513-7188

\section{Suheyla Ocak}

Istanbul Universitesi Istanbul Tip Fakultesi

\section{Begum Sirin Koc}

Istanbul Universitesi-Cerrahpasa

\section{Melike Sezgin Evim}

Uludag Universitesi Tip Fakultesi

\section{Ozlem Tufekci}

Dokuz Eylul Universitesi Tip Fakultesi

\section{Gulen Tuysuz Kintrup}

Akdeniz Universitesi Tip Fakultesi

\section{Utku Aygünes}

Konya Egitim ve Arastirma Hastanesi

Ibrahim Eker

Afyonkarahisar Saglik Bilimleri Universitesi

\section{Basak Unver Koluman}

Pamukkale Universitesi Tip Fakultesi

\section{Gul Ilhan}

Mustafa Kemal Universitesi Tayfur Ata Sokmen Tip Fakultesi

\section{Neslihan Andic}

Eskisehir Osmangazi Universitesi Tip Fakultesi

\section{Ersin Toret}

Eskisehir Osmangazi Universitesi Tip Fakultesi

\section{Ayse Burcu Akinci}

Canakkale Onsekiz Mart Universitesi Tip Fakultesi

\section{Burcak Tatli Gunes}

Turkiye Cumhuriyeti Saglik Bakanligi Izmir Tepecik Egitim ve Arastirma Hastanesi

\section{Fergun Yilmaz}

Marmara Universitesi Egitim ve Arastirma Hastanesi

\section{Dilek Gurlek Gokcebay}

Ankara City Hospital

\section{Tugba Belgemen Ozer}


Medeniyet Universitesi Goztepe Egitim ve Arastirma Hastanesi

\section{Melek Isik}

Ankara City Hospital

\section{Yesim Oymak}

Doktor Behcet Uz Cocuk Hastaliklari ve Cerrahisi Egitim ve Arastirma Hastanesi

\section{Berna Atesagaoglu}

Balikesir State Hospital

\section{Isil Erdogan Ozunal}

Medeniyet Universitesi Goztepe Egitim ve Arastirma Hastanesi

\section{Mustafa Duran}

Konya Egitim ve Arastirma Hastanesi

\section{Deniz Ozel Erkan}

Akdeniz Universitesi

\section{Erol Gurpinar}

Akdeniz Universitesi Tip Fakultesi

\section{Yesim Aydinok}

Ege Universitesi Tip Fakultesi

\section{Research article}

Keywords: transfusion medicine, education, medical students, transfusion, transfusion risks, transfusion reaction, Turkish

Posted Date: January 29th, 2020

DOI: https://doi.org/10.21203/rs.2.22224/v1

License: (c) (i) This work is licensed under a Creative Commons Attribution 4.0 International License. Read Full License 


\section{Abstract}

Background: Proper clinical use of blood products requires competent theoretical and practical knowledge of transfusion medicine. In this study, we aimed to evaluate levels of transfusion medicine knowledge and attainment of educational targets and identify factors affecting the education of transfusion medicine.

Methods: A multicentric survey study was performed among final-year medical students. The questions were prepared based on learning objectives for transfusion medicine curriculum. The questionnaire focused on the safety of blood transfusion administration.

Results: The survey included 727 (24\%) of 3009 students enrolled in 13 medical schools. In the competence self-assessment, $65 \%$ of the students reported that transfusion medicine education was insufficient. Only $14 \%$ felt competent in recognizing transfusion complications and applying first-line treatment. For initiating and monitoring transfusions, $41 \%$ stated they could manage under supervision and $7 \%$ stated they had sufficient practice, while the remaining $52 \%$ considered themselves completely insufficient in this area. The 10 questions assessing basic knowledge and attainment of educational targets had 53 choices. This indicates that intern doctors were not able to recognize $50 \%$ of the correct and $30 \%$ of the incorrect information.

Conclusion: A large proportion of medical students did not have adequate theoretical knowledge or selfassessed practical competency in transfusion medicine.

\section{Background}

Transfusion is an indispensable procedure in all medical and surgical specialties. While transfusion of blood and its components may be life-saving, inappropriate clinical use may result in serious morbidity and even death. Studies on transfusion medicine have focused on the appropriate use of blood [1-3]. Blood and blood products are commonly used in the hospital setting, and it is imperative that physicians possess at least basic theoretical and practical knowledge of transfusion medicine to ensure their proper usage [4-7].

Although physicians follow developments in other medical fields and current information on diagnostics and treatment practices more closely, they show less interest in improvements in appropriate use of blood products [8-10]. Knowledge of transfusion medicine is usually based on clinical training and conventional education [4-7].

It is clear that transfusion training should be given properly in order to improve transfusion practices [11]. Studies evaluating transfusion medicine education in both developed and developing countries have revealed a lack of standardization between countries and even within faculties in the same country, at both the undergraduate and postgraduate levels $[12,13]$. In response, several countries have scrutinized 
their own education systems and proposed suggestions to improve transfusion medicine education [4, $10,12-14]$.

Medical schools in Turkey use the discipline-based model. In order to improve the education and training provided in medical faculties and raise them to international standards, the National Core Education Program (NCEP) for medical school curricula was updated and all medical schools were asked to implement the 2014 NCEP. In addition, medical schools inside of Turkey accredited by the Association for Evaluation and Accreditation of Medical Education Programs (TEPDAD) under the World Medical Education Federation establish their educational curricula in accordance with the 2014 NCEP.

Few studies have investigated the quality and nature of transfusion medicine education [12]. The purpose of our study was to evaluate the knowledge and perceptions of competence regarding transfusion medicine among intern doctors in Turkey. Determining the efficiency of transfusion medicine education at the undergraduate level in Turkish medical schools may help to understand the capability of newly graduated doctors who may be residents in medical fields where appropriate patient blood management will be lifesaving.

\section{Methods}

This study was planned as a multicenter survey study of final-year medical students in their last internship before graduation from medical school. Sample size and distribution were determined using a stratified sampling method to represent 13 medical schools in direct proportion to the number of students enrolled in each faculty of medicine.

Survey questions were prepared by expert faculty members and included basic information that should be known considering the NCEP 'Blood Banking and Transfusion Medicine' educational targets. The survey form is presented in supplementary material.

The survey consisted of two parts. In the first part, students rated their perceived competence in transfusion medicine and blood banking. The second part included 10 multiple-choice theoretical questions with a total of 53 options. Each of the options contained either correct or incorrect information, and the students were asked to mark all of the choices they believed to be correct. Each of options was evaluated as a separate data point. Current information about the medical schools participating in the survey was recorded (Table 1 ).

The survey questions were assessed in terms of suitability for measurement and evaluation by faculty members in the Department of Medical Education and in the Faculty of Education, Division of Measurement and Evaluation. After testing the comprehensibility of the survey with a pilot study, it was applied through one-on-one interviews with each of the students in the study group.

Statistical analyses were performed using IBM SPSS v.23 statistical software with support from the Akdeniz University Statistical Consulting Unit. Chi-square test was used for parametric tests and Mann- 
Whitney test for nonparametric tests, with $p<0.05$ accepted as significant.

After obtaining local ethics committee approval (UHS-2018-135), the study was performed via one-on-one interviews with the students by the selected hematologist from each medical school participating in the study.

\section{Results}

This multicenter study included 727 of a total of 3009 intern doctors in 13 medical faculties. Proportional representation of each faculty was ensured as follows: 112 of 470 interns in Istanbul University, Istanbul Faculty of Medicine (23.8\%, 101 of 430 in Istanbul University, Cerrahpasa Faculty of Medicine (23.4\%), 81 of 343 in Ege University (23.6\%), 71 of 300 in Uludağ University (23.6\%), 70 of 282 in Dokuz Eylül University (24.8\%), 55 of 226 in Akdeniz University (24.3\%), 47 of 200 in Cumhuriyet University (23.5\%), 45 of 184 in Osmangazi University (24.4\%), 35 of 143 in Mustafa Kemal University (24.4\%), 35 of 138 in Afyon Kocatepe University (25.3\%), 30 of 119 in Pamukkale University (25.2\%), 25 of 94 in Katip Çelebi University (26.5\%), and 20 of 80 in Onsekiz Mart University (25\%).

Within the study group, $15.4 \%$ of the interns were from Istanbul University, Istanbul Faculty of Medicine, 13.9\% from Istanbul University, Cerrahpasa Faculty of Medicine, 11.1\% from Ege University, 9.8\% from Uludag University, 9.6\% from Dokuz Eylül University, 7.6\% from Akdeniz University, 4.8\% from Afyon Kocatepe University, 4.1\% from Pamukkale University, 3.4\% from Katip Celebi University, and 2.8\% from Onsekiz Mart University.

\section{Self-reported competence:}

Students rated their opinion regarding whether the transfusion medicine education provided in their medical school was sufficient using a 5-point scale (1: Strongly disagree, 2: Disagree, 3: Partially agree, 4: Agree, 5: Strongly agree). The mean score was $2.22 \pm 0.91$ (median: 2), indicating that the interns generally considered the education to be insufficient. Only $2 \%$ of intern doctors strongly agreed that the education was sufficient, while a total of $65 \%$ disagreed or strongly disagreed (Table 2 ).

The students then evaluated their ability to recognize transfusion complications and administer the firstline treatment using a 3-point scale (1: I cannot determine a prediagnosis, 2: I can determine a prediagnosis but not intervene, 3 : I can determine a prediagnosis and administer the first-line treatment). The mean score was $1.83 \pm 0.65$ (median: 2 ), with the majority stating they could diagnose but not treat. Only $14 \%$ of the students felt competent in recognizing transfusion complications and applying the firstline treatment (Table 2). Although being able to recognize transfusion complications at the prediagnosis level is an NCEP educational target, $30 \%$ of the students did not express confidence in the prediagnosis of transfusion complications.

When the students rated their perceived competence in initiating and monitoring blood transfusions on a 3-point scale (1: I do not feel competent, 2: I can do under supervision in case of emergency, 3: I am 
competent), the mean score was $1.56 \pm 0.62$ (median: 1 ). Only $7 \%$ of intern doctors felt completely capable, $41 \%$ said they could manage under supervision in case of emergency, and the other half of the students (52\%) felt completely unprepared to initiate and monitor blood transfusions (Table 2).

There were significant but weak correlations between total score and perceived competence in recognizing and treating transfusion complications $(p<0.001, r=0.149)$ and in starting and monitoring blood transfusion $(p=0.002, r=0.115)$.

\section{Assessment of theoretical knowledge:}

The students were presented with 53 choices under 10 questions and asked to indicate all correct answers. The students selected a mean of $13 \pm 3.5$ (median: 13) of the total of 26 right answers, while they incorrectly chose a mean of $8 \pm 3.1$ (median: 8 ) of the total 27 wrong answers. Their mean net score was calculated as $5 \pm 3.7$ (median 5). This showed that among very basic and practical transfusion information, intern doctors approaching medical school graduation were unable to recognize $50 \%$ of the correct answers and 30\% of the incorrect answers. Striking examples of right and wrong answers that the students missed are presented in Tables 3 and 4, respectively, together with student percentages. Distribution of scores according to the characteristics of the students' medical schools is presented in Table 5.

\section{Evaluation of factors affecting education:}

While 10 of the 13 faculties represented in our study had theoretical courses in their curriculum, only 6 offered practical training. Although theoretical education was not associated with total scores $(p=0.873)$, students attending faculties with practical training had significantly lower scores $(p=0.017)$.

For $72.5 \%$ (525) of students, the blood banks of their faculty hospital were operating as temporary blood centers, and these students had significantly higher scores than students from hospitals that were structured as blood bank transfusion centers $(\mathbf{p}=\mathbf{0 . 0 0 3})$. Higher annual amount of blood products transfused in a faculty was associated with the students' knowledge level $(p=0,002)$.

When the medical schools were evaluated with regard to their faculty member to student ratio, the results ranged from 2:1 to 1:12. After grouping based on student to faculty ratio $(\leq 5,6-10, \geq 11)$, no significant association with total scores was observed $(p=0.638)$.

In the 7 faculties that had National Medical Education Accreditation and adopted the NCEP as their curriculum, $72 \%$ of students received education on transfusion medicine, but being an accredited university was not shown to have any effect on the students' knowledge level $(p=0.554)$.

Receiving education from an accredited faculty, blood bank structuring, student to faculty member ratio, receiving theoretical and practical courses in the curriculum, and annual amount of blood transfusion were not associated with students' perceptions of the adequacy of their transfusion medicine education 
or their competence in recognizing and managing transfusion complications or initiating and monitoring transfusion $(p<0.05)$.

\section{Discussion}

Basic transfusion medicine curricula should cover good clinical use of blood and blood products and the principles of proper implementation of transfusion services during physicians' specialist training.

Medical students and residents in internal and surgical specialties should have accurate and comprehensive information on the use of blood and blood products. A study by Flausino et al. revealed that young physicians in particular do not have sufficient information on the indications and complications of the use of blood products [4]. O'Brien and colleagues also evaluated the knowledge level of 116 recently graduated physicians on transfusion medicine with standard patient practices and written examination, and emphasized the lack of sufficient information in this field [15]. Only $17 \%$ of the residents knew what "TRALI" was (transfusion-related acute lung injury), while none of the residents assistant knew that irradiating blood products would prevent graft-versus-host disease. Similarly, our study demonstrated that medical students nearing graduation generally did not feel competent in transfusion medicine and did not possess basic knowledge about blood transfusion. In our study, almost half of the medical students who were about to graduate believed that febrile nonhemolytic reactions could be prevented by irradiation, and hardly any of the interns knew the universal donor group for fresh frozen plasma (FFP). The deficiency of basic theoretical and practical knowledge of transfusion medicine among these interns, who will work in emergency departments or enter residency programs after graduation, was a finding that warrants concern. Karp et al. advised awareness of this in disciplines where transfusion is practiced frequently during resident training and said that new graduates should also realize that they are not well-equipped for transfusion. We have reached similar conclusions based on our results, and we believe that providing focused education on blood banking and transfusion practices to first-year residents in departments with frequent transfusion procedures will improve patient care and safety [16].

Panzer et al. evaluated transfusion medicine curricula in 14 countries and determined that the content, training methods, duration, and timing of undergraduate transfusion medicine education vary widely between medical schools [12]. In Australia, while there is theoretical training, there are no training programs available to support students' clinical skills. The curriculum has broader content in Israel and is covered as mandatory courses in France. Since transfusion medicine is regarded as a separate area of expertise in Germany, it is included in a separate training module and practical transfusion training is conducted bedside. In the United States, despite the frequent use of blood components and allocation of funds for transfusion medicine training, a standardized curriculum has not been developed [12].

Although there is substantial variability in transfusion medicine education globally, the coverage of transfusion medicine and blood banking in medical school curricula is typically limited and general [13, 15]. In most medical schools, transfusion medicine is covered as a part of bedside clinical training [4]. 
Since studies revealed the inadequacy of basic and continuing education on transfusion medicine in Brazil, research has focused on the dissemination of accredited transfusion medicine training programs $[13,17]$.

In African countries, transfusion medicine training has assumed an important place in the fight against AIDS. However, it was observed that physician training in transfusion medicine in most African countries was limited to only 1- or 2-hour courses. This awareness led to the creation and implementation of training programs appropriate to local conditions [13]. Our study revealed that some medical schools in Turkey still allocate only 1 or 2 teaching hours to transfusion medicine.

In their study on transfusion medicine training in developing countries, Eichbaum et al. reported that each country is trying to determine their current situation and to develop training plans to improve local transfusion medicine practices within the framework of its national health policies. [13].

Our study is the most comprehensive study conducted on this topic in our country. For a physician who has graduated from a Turkish medical school, the learning outcomes of the NCEP state that "they should be aware of blood and blood product transfusion complications at the preliminary diagnosis level and should know enough to refer to the relevant specialist after performing the necessary pre-treatment." and "In an emergency, they should have the ability to practice blood transfusions in accordance with the guidelines." However, the result of our study showed that only $15 \%$ of final-year students close to graduation had achieved this learning objective. Considering that transfusion complications are urgent and may require life-saving intervention, the ratio of physicians who think that the learning target has been reached is quite insufficient.

The NCEP educational outcome for blood banking states that a graduate of medical school "recognizes complications of blood and blood product transfusion at prediagnosis level". In our study, one-third of medical students near graduation stated that they could not determine the prediagnosis. Considering the urgency of potential transfusion-related complications, it is clear that this educational target is not being adequately met.

Similar studies helped identify deficits in transfusion medicine education in Iran. These studies suggested that $80 \%$ of Iranian medical schools did not provide effective theoretical and practical transfusion medicine training. In addition, they pointed out the lack of basic education in transfusion medicine, which is needed not only by medical students and general practitioners but also by medical staff. Taking the example of training programs around the world and targeting different levels of education, a training program was adapted to conditions in Iran and was reported to have had a vital role in improving patient safety and reducing the high cost of treatment with blood products $[10,18]$

The students participating in the present study evaluated the education in their medical schools as insufficient. These 6-year medical curricula include a total of 0-4 hours of theoretical courses about blood banking and transfusion medicine, with no standardization in terms of which department is responsible for giving the course or the number of course hours. We have argued that 1 to 4 hours of 
theoretical training during 6 years of education is grossly insufficient for meeting the educational need in blood banking and transfusion medicine and has essentially no educational value. Our findings support this, as there was no significant relationship between receiving theoretical education and the students' knowledge level or self-perceived competence.

If the current approach provides no educational benefit, the methods, contents, and objectives of the training should be reevaluated and the programs revised accordingly. For example, centralized education was not effective in China, whereas extremely successful outcomes were obtained with locally structured education [13].

An interesting finding in our study was that students receiving practical training scored lower in questions assessing theoretical knowledge. Assuming that the training they received is mostly based on bedside clinical training and mentor-apprentice relationships, this paradoxical result may be attributable to the transfer of inaccurate information and practice. Evaluating the content and delivery methods of these schools' programs and interviewing lecturers may help identify failures in practical applications. Holding focus group discussions with the students in these schools may also help identify the problem by analyzing it in its natural environment.

In faculties with blood banks, blood centers procuring their own blood products will provide more encounters with blood banking, apheresis procedures, and donors during students' education, which can have a positive contribution on the education on blood banking and transfusion medicine.

One of the most common practices physicians encounter during their career is the use of blood products. However, we have demonstrated that medical students nearing graduation do not possess even very basic information about the properties of blood products. Lack of this information can lead to make medical mistakes that may result in serious complications. Therefore, we believe that medical school curricula must be revised in terms of blood banking and the objectives and content of medical education.

A lack of knowledge of transfusion medicine among physicians is common to both underdeveloped areas such as Africa, where there are fewer than 100 physicians trained in transfusion medicine per country, and developed nations such as the USA, which has some of the most advanced transfusion medicine training in the world. This clearly demonstrates the need to improve and disseminate transfusion medicine training globally [13].

The best way to reduce adverse events associated with blood transfusion is to decrease the number of unnecessary and noncompliant transfusions. The current curriculum is somewhat limited in terms of the rational use of blood and its components. Establishing regulations targeting the appropriate use of blood products with theoretical and practical training will create better equipped physicians and prevent many complications and unnecessary transfusions.

\section{Conclusions}


Our results in this study suggest that medical schools are not producing physicians who are sufficiently knowledgeable and competent in transfusion medicine. At least, final-year medical students did not feel sufficient in this area. More current and extensive knowledge of transfusion medicine can be provided to physicians in training through the reevaluation of transfusion medicine practices and educational targets

by a commission consisting of competent academicians, standardization of educational approaches and curricula, and clearer delegation of this educational responsibility. The results of this study were evaluated at a meeting of TEPDAD and efforts are underway to review the contents of transfusion medicine education in Turkish medical schools and reform this part of the curriculum.

Study Limitations: It is not entirely correct to deem transfusion medicine education insufficient based on results obtained from a limited number of theoretical questions asked to students. However, these questions covered very basic information about the properties of blood products and transfusion indications and complications, and the expert consensus was that physicians without this minimal level of knowledge could pose a serious threat to patient safety. Therefore, the inadequate transfer of such basic information indicates a shortcoming in the medical education system that should be taken seriously.

\section{Declarations}

- Ethics approval and consent to participate: Ethics committee approval (2018-135) was received for the study by the Health Sciences University Education and Research Hospital. A questionnaire was applied after obtaining written and verbal informed consent from all participants.

- Consent for publication: Not applicable

- Availability of data and materials: The datasets used and/or analysed during the current study are available from the corresponding author on reasonable request.

- Competing interests: The authors have no conflicts of interest to declare.

- Funding: No research funding has been received for this research.

- Authors' contributions: F. Kupesiz, S. Ocak, B. Koc, M. Evim, O. Tufekci, G. Kintrup, U. Aygun, I. Eker, B. Koluman, G. Ilhan, N. Andic, E. Toret, A. Akinci, B. Gunes, A. Yilmaz, D. Gokcebay, T. Ozer, M. Isik, Y. Oymak, B. Atesagaoğlu, I. Ozunal, M. Duran, D. Erkan, E. Gurpinar, Y. Aydinok contributed to the conception or design of the study and provided final approval of the published version. S. Ocak, B. Koc, M. Evim, O. Tufekci, G. Kintrup, U. Aygun, I. Eker, B. Koluman, G. Ilhan, N. Andic, E. Toret, A. Akinci, B. Gunes, A. Yilmaz, Y. Aydinok were applied through one-on-one interviews with each of the students in the study group. Y. Aynidok, F. Kupesiz, and D. Ozel, performed data analysis and interpretation. Y. Aydinok, F. Kupesiz, and N. Andac evaluated the manuscript and have drafted the work or substantively revised it.

- Acknowledgements: The authors thank Assistant Professor Hakan Kogar of Akdeniz University, Faculty of Education, Department of Measurement and Evaluation (Antalya) for assessing the suitability of 
survey questions in terms of measurement and evaluation. This study was conducted as a project in the Turkish Society of Hematology 'Transfusion Medicine and Apheresis Master Class'.

\section{Abbreviations}

- AIDS: Acquired Immune Deficiency Syndrome

- FFP: Fresh frozen plasma

- TEPDAD: The Association for Evaluation and Accreditation of Medical Education Programs

- NCEP: The National Core Education Program

- USA: The United States of America

\section{References}

1. Tinmouth, A., Reducing the amount of blood transfused by changing clinicians' transfusion practices. Transfusion, 2007. 47(2 Suppl): p. 132S-136S; discussion 155S-156S.

2. Tinmouth, A., et al., Reducing the amount of blood transfused: a systematic review of behavioral interventions to change physicians' transfusion practices. Arch Intern Med, 2005. 165(8): p. 845-52.

3. Rothschild, J.M., et al., Assessment of education and computerized decision support interventions for improving transfusion practice. Transfusion, 2007. 47(2): p. 228-39.

4. Flausino Gde, F., et al., Teaching transfusion medicine: current situation and proposals for proper medical training. Rev Bras Hematol Hemoter, 2015. 37(1): p. 58-62.

5. Graham, J., et al., Assessing transfusion competency in junior doctors: a retrospective cohort study. Transfusion, 2014. 54(1): p. 128-36.

6. Graham, J.E., Transfusion e-learning for junior doctors: the educational role of 'LearnBloodTransfusion'. Transfus Med, 2015. 25(3): p. 144-50.

7. Graham, J.E., S. Narayan, and K. Pendry, Improving transfusion education for junior doctors; exploring UK experiences. Transfus Med, 2017. 27(2): p. 96-104.

8. Lin, Y., et al., BEST-TEST2: assessment of hematology trainee knowledge of transfusion medicine. Transfusion, 2016. 56(2): p. 304-10.

9. Haspel, R.L., et al., Internal medicine resident knowledge of transfusion medicine: results from the BEST-TEST international education needs assessment. Transfusion, 2015. 55(6): p. 1355-61.

10. Javadzadeh Shahshahani, H., Status of Transfusion Medicine Education in Iran. Arch Iran Med, 2016. 19(6): p. 439-45.

11. Rock, G., et al., A pilot study to assess physician knowledge in transfusion medicine. Transfus Med, 2002. 12(2): p. 125-8.

12. Panzer, S., et al., Education in transfusion medicine for medical students and doctors. Vox Sang, 2013. 104(3): p. 250-72. 
13. Eichbaum, Q., et al., Global health and transfusion medicine: education and training in developing countries. Transfusion, 2014. 54(7): p. 1893-8.

14. Zeller, M.P., et al., Design and Implementation of a Competency-Based Transfusion Medicine Training Program in Canada. Transfus Med Rev, 2016. 30(1): p. 30-6.

15. O'Brien, K.L., et al., Transfusion medicine knowledge in Postgraduate Year 1 residents. Transfusion, 2010. 50(8): p. 1649-53.

16. Karp, J.K., C.M. Weston, and K.E. King, Transfusion medicine in American undergraduate medical education. Transfusion, 2011. 51(11): p. 2470-9.

17. Maiolino, A. and N. Spector, Challenges for medical residency in hematology and transfusion medicine in Brazil. Rev Bras Hematol Hemoter, 2012. 34(5): p. 321-2.

18. Gharehbaghian, A., et al., Assessment of physicians knowledge in transfusion medicine, Iran, 2007. Transfus Med, 2009. 19(3): p. 132-8.

\section{Tables}

\section{Table 1: Information on faculties about education and blood banking}

\section{Name of medical school:}

When was the medical school founded?

What department of the medical school is responsible for the blood bank?

What is the ratio of students to faculty members in the medical school?

What is the inpatient bed capacity of the hospital?

What is the annual consumption of blood and blood products in the hospital?

How is your blood bank structured?

How many hours of theoretical and practical instruction related to transfusion medicine and blood banking are in the curriculum?

Table 2: Distribution of scores in the students' self-evaluation of competence 


\begin{tabular}{|c|c|c|c|c|}
\hline \multirow{2}{*}{ Question } & \multirow{2}{*}{ Response } & \multirow{2}{*}{$\begin{array}{l}\mathrm{n} \\
(\%)\end{array}$} & \multicolumn{2}{|c|}{$\begin{array}{l}\text { Net Points in } \\
\text { test }\end{array}$} \\
\hline & & & $\begin{array}{r}\text { mean } \\
\pm \\
(\mathrm{SD})\end{array}$ & Med. \\
\hline \multirow{5}{*}{$\begin{array}{l}\text { Do you think the education on } \\
\text { Transfusion Medicine is sufficient in } \\
\text { the medical school? }\end{array}$} & Strongly disagree & $\begin{array}{l}161 \\
(22)\end{array}$ & $\begin{array}{l}4.60 \pm \\
(3.42)\end{array}$ & 5.00 \\
\hline & Disagree & $\begin{array}{l}311 \\
(43)\end{array}$ & $\begin{array}{l}4.94 \pm \\
(3.58)\end{array}$ & 5.00 \\
\hline & Partially agree & $\begin{array}{l}205 \\
(28)\end{array}$ & $\begin{array}{l}4.96 \pm \\
(3.87)\end{array}$ & 5.00 \\
\hline & Agree & $\begin{array}{l}35 \\
(5)\end{array}$ & $\begin{array}{l}4.49 \pm \\
(3.27)\end{array}$ & 4.00 \\
\hline & Strongly agree & $\begin{array}{l}15 \\
(2)\end{array}$ & $\begin{array}{l}5.2 \pm \\
(5.1)\end{array}$ & 4.00 \\
\hline \multirow{3}{*}{$\begin{array}{l}\text { How competent do you feel regarding } \\
\text { complications related to blood and } \\
\text { blood product transfusion? }\end{array}$} & $\begin{array}{l}\text { I can't determine the pre- } \\
\text { diagnosis }\end{array}$ & $\begin{array}{l}223 \\
(31)\end{array}$ & $\begin{array}{l}4.11 \pm \\
(3.40)\end{array}$ & 4.00 \\
\hline & $\begin{array}{l}\text { I can determine the pre- } \\
\text { diagnosis but I can't apply } \\
\text { any treatment }\end{array}$ & $\begin{array}{l}403 \\
(55)\end{array}$ & $\begin{array}{l}5.00 \pm \\
(3.64)\end{array}$ & 5.00 \\
\hline & $\begin{array}{l}\text { I can determine the pre- } \\
\text { diagnosis, and I can apply } \\
\text { first-line treatment }\end{array}$ & $\begin{array}{l}101 \\
(14)\end{array}$ & $\begin{array}{l}5.92 \pm \\
(3.89)\end{array}$ & 6.00 \\
\hline \multirow{3}{*}{$\begin{array}{l}\text { How competent do you feel in } \\
\text { initiating and monitoring the } \\
\text { transfusion of blood and blood } \\
\text { products? }\end{array}$} & $\begin{array}{l}\text { I don't find myself } \\
\text { competent }\end{array}$ & $\begin{array}{r}374 \\
(51)\end{array}$ & $\begin{array}{l}4.43 \pm \\
(3.38)\end{array}$ & 5.00 \\
\hline & $\begin{array}{l}\text { I can apply it by receiving } \\
\text { support in an emergency }\end{array}$ & $\begin{array}{r}302 \\
(42)\end{array}$ & $\begin{array}{l}5.21 \pm \\
(3.85)\end{array}$ & 5.00 \\
\hline & $\begin{array}{l}\text { I have competence in this } \\
\text { application }\end{array}$ & $\begin{array}{r}51 \\
(7)\end{array}$ & $\begin{array}{l}5.90 \pm \\
(3.91)\end{array}$ & 6.00 \\
\hline
\end{tabular}

Table 3. Correct answers not recognized as correct by the students 


\begin{tabular}{|c|c|}
\hline $\begin{array}{c}\text { Percent } \\
\text { missed } \\
(\%)\end{array}$ & Question \\
\hline & $\begin{array}{l}\text { Which actions would you take if a patient developed fever of } 38.5^{\circ} \mathrm{C} \text { with } \\
\text { chills during the transfusion of red cell suspension? }\end{array}$ \\
\hline $76 \%$ & Perform direct antiglobulin test \\
\hline $70 \%$ & Give antipyretics to the patient \\
\hline $66 \%$ & Perform blood culture \\
\hline & $\begin{array}{l}\text { Which actions can be performed to prevent febrile nonhemolytic transfusion } \\
\text { reaction? }\end{array}$ \\
\hline $84 \%$ & Give antipyretics to the patient before transfusion \\
\hline $42 \%$ & Perform leukocyte filtration on the blood unit \\
\hline & Which of the following products do not require cross-match? \\
\hline $51 \%$ & Platelet suspension \\
\hline $45 \%$ & Cryoprecipitate \\
\hline $42 \%$ & Fresh frozen plasma \\
\hline & Which of the following statements are correct about platelet suspensions? \\
\hline $81 \%$ & $\begin{array}{l}\text { The possibility of bacterial contamination is higher with platelet suspension } \\
\text { than red cell suspension }\end{array}$ \\
\hline $55 \%$ & The storage period of platelet suspension is 5 days \\
\hline $54 \%$ & ABO-Rh(D) compliance should be investigated for platelets. \\
\hline & $\begin{array}{l}\text { Which of the following statements are correct about transfusion of red cell } \\
\text { suspension? }\end{array}$ \\
\hline $59 \%$ & $\begin{array}{l}\text { Transfusion of red cell suspension should be completed within } 4 \text { hours at the } \\
\text { latest }\end{array}$ \\
\hline $88 \%$ & $\begin{array}{l}\text { In emergencies with patients of unknown blood group, the group of fresh } \\
\text { frozen plasma (FFP) that may be administered is group AB }\end{array}$ \\
\hline
\end{tabular}

Table 4. Incorrect answers not recognized as incorrect by the students 


\begin{tabular}{|l|l|}
\hline $\begin{array}{l}\text { Percent } \\
\text { selected } \\
(\%)\end{array}$ & \\
\hline $81 \%$ & $\begin{array}{l}\text { In emergencies with patients of unknown blood group, the fresh frozen } \\
\text { plasma (FFP) that may be administered is group O }\end{array}$ \\
\hline $43 \%$ & $\begin{array}{l}\text { Febrile nonhemolytic transfusion reaction can be prevented by irradiation } \\
\text { of blood product }\end{array}$ \\
\hline $35 \%$ & FFP is used as an albumin source \\
\hline $34 \%$ & FFP is used as an immunoglobulin source \\
\hline $14 \%$ & $\begin{array}{l}\text { There is no need for cross-match of red cell suspension and fresh whole } \\
\text { blood }\end{array}$ \\
\hline $7 \%$ & The universal donor for red cell suspension is the AB Rh(D)-negative. \\
\hline
\end{tabular}

Table 5. Distribution of points according to faculty characteristics 


\begin{tabular}{|c|c|c|c|c|}
\hline \multirow{2}{*}{\multicolumn{2}{|c|}{ Faculty Characteristics }} & \multirow{2}{*}{$\begin{array}{c}\text { n (\%) } \\
112 \\
(15.4)\end{array}$} & \multicolumn{2}{|c|}{ Net Points in test } \\
\hline & & & Mean \pm SD & Median \\
\hline $\begin{array}{l}\text { Faculties } \\
\text { (N: total number of intern) }\end{array}$ & $\begin{array}{l}\text { 1. Faculty (470) } \\
\text { 2. Faculty (430) } \\
\text { 3. Faculty (343) } \\
\text { 4. Faculty (300) } \\
\text { 5. Faculty (282) } \\
\text { 6. Faculty (226) } \\
\text { 7. Faculty (200) } \\
\text { 8. Faculty (184) } \\
\text { 9. Faculty (143) } \\
\text { 10. Faculty (138) } \\
\text { 11. Faculty (119) } \\
\text { 12. Faculty (94) } \\
\text { 13. Faculty (80) }\end{array}$ & $\begin{array}{c}112 \\
(15.4) \\
101 \\
(13.9) \\
81 \\
(11.1) \\
71(9.8) \\
70(9.6) \\
55(7.6) \\
47(6.5) \\
45(6.2) \\
35(5) \\
35(4.8) \\
30(4.1) \\
25(3.4) \\
20(2.8)\end{array}$ & $\begin{array}{l}5.20 \pm \\
(3.62) \\
\\
4.89 \pm \\
(3.57) \\
\\
4.64 \pm \\
(3.48) \\
5.20 \pm \\
(3.88) \\
5.14 \pm \\
(3.24) \\
4.58 \pm \\
(4.06) \\
\\
3.38 \pm \\
(3.87) \\
5.62 \pm \\
(3.64) \\
6.97 \pm \\
(3.81) \\
4.31 \pm \\
(3.53) \\
3.03 \pm \\
(2.70) \\
4.28 \pm \\
(3.14) \\
4.55 \pm \\
(3.33)\end{array}$ & $\begin{array}{l}6.00 \\
5.00 \\
5.00 \\
5.00 \\
5.50 \\
5.00 \\
4.00 \\
6.00 \\
7.00 \\
5.00 \\
3.00 \\
4.00 \\
4.00\end{array}$ \\
\hline Is it an accredited university? & $\begin{array}{l}\text { Yes } \\
\text { No }\end{array}$ & $\begin{array}{l}527 \\
(73) \\
200 \\
(27)\end{array}$ & $\begin{array}{l}4.92 \pm \\
(3.62) \\
\\
4.68 \pm \\
(3.71)\end{array}$ & $\begin{array}{l}5.00 \\
5.00\end{array}$ \\
\hline Blood bank structure & $\begin{array}{l}\text { University's blood } \\
\text { bank } \\
\text { Red Crescent Blood } \\
\text { Center }\end{array}$ & $\begin{array}{l}202 \\
(28) \\
525 \\
(72)\end{array}$ & $\begin{array}{l}4.22 \pm \\
(3.45) \\
\\
5.10 \pm \\
(3.66)\end{array}$ & $\begin{array}{l}4.00 \\
5.00\end{array}$ \\
\hline $\begin{array}{l}\text { The number of students per faculty } \\
\text { member }\end{array}$ & $\begin{array}{l}\leq 5 \\
6-10\end{array}$ & $\begin{array}{l}191 \\
(26)\end{array}$ & $\begin{array}{l}4.95 \pm \\
(3.42)\end{array}$ & $\begin{array}{l}5.00 \\
5.00\end{array}$ \\
\hline
\end{tabular}




\begin{tabular}{|c|c|c|c|c|}
\hline & $>10$ & $\begin{array}{c}465 \\
(64) \\
71(10)\end{array}$ & $\begin{array}{l}4.76 \pm \\
(3.71) \\
\\
5.20 \pm \\
(3.88)\end{array}$ & 5.00 \\
\hline Hospital bed capacity & $\begin{array}{l}\leq 1000 \\
>1000\end{array}$ & $\begin{array}{l}261 \\
(36) \\
466 \\
(64)\end{array}$ & $\begin{array}{l}5.00 \pm \\
(3.68) \\
4.77 \pm \\
(3.63)\end{array}$ & $\begin{array}{l}5.00 \\
5.00\end{array}$ \\
\hline $\begin{array}{l}\text { The number of transfusions per year in } \\
\text { the hospital }\end{array}$ & $\begin{array}{l}\leq 10000 \\
10001-25000 \\
25001-50000 \\
\geq 50000\end{array}$ & $\begin{array}{c}55(8) \\
183 \\
(25) \\
\\
282 \\
(39) \\
\\
207 \\
(28)\end{array}$ & $\begin{array}{l}4.40 \pm \\
(3.43) \\
4.90 \pm \\
(3.86) \\
4.94 \pm \\
(3.46) \\
4.82 \pm \\
(3.77)\end{array}$ & $\begin{array}{l}4.00 \\
5.00 \\
5.00 \\
5.00\end{array}$ \\
\hline Theoretical courses in the curriculum & $\begin{array}{l}\text { Yes } \\
\text { None }\end{array}$ & $\begin{array}{l}581 \\
(80) \\
146 \\
(20)\end{array}$ & $\begin{array}{l}4.85 \pm \\
(3.59) \\
4.88 \pm \\
(3.87)\end{array}$ & $\begin{array}{l}5.00 \\
5.00\end{array}$ \\
\hline Practical courses in the curriculum & $\begin{array}{l}\text { Yes } \\
\text { None }\end{array}$ & $\begin{array}{l}319 \\
(44) \\
408 \\
(56)\end{array}$ & $\begin{array}{l}.53 \pm \\
(3.57) \\
\\
5.11 \pm \\
(3.69)\end{array}$ & $\begin{array}{l}4.00 \\
5.00\end{array}$ \\
\hline
\end{tabular}

\section{Supplementary Files}

This is a list of supplementary files associated with this preprint. Click to download.

- SupplementaryMaterial.doc 